\title{
INTRODUCTION
}

\section{WESTERN POLICIES AND THE IMPACT OF TRADITION AT CRITICAL JUNCTURES: THE BALTIC STATES AFTER THE FIRST WORLD WAR AND THE COLD WAR}

\author{
Kaarel Piirimäe, with Maria Mälksoo
}

\begin{abstract}
Against the backdrop of the war and revolution in Ukraine, and Russia's seeming return to the Cold War mentality and confrontation with the West, the Baltic states look increasingly "normal" among the states of the former Soviet Union. Apart from the long-established Western fear of instability resulting from the Russian minority issue, ${ }^{1}$ Baltic anxieties about the Russian military power and intentions, international press has not had much sensational to report about the Baltic states in recent years. Their political development seems to be following the trajectory of long-consolidated European democracies. Indeed, their twenty-five-year path from Soviet republics to EU member states looks even more spectacular after the recent rise of concerns over democracy in Hungary and Poland - countries long considered the exemplary democratic transition states of the former Warsaw Pact along with Czechoslovakia, all of which had a much better initial starting position in terms of political-economic reform compared to the former Soviet republics of Estonia, Latvia and Lithuania in the early 1990 s. $^{2}$
\end{abstract}

\footnotetext{
${ }^{1}$ With a potential of triggering international crises and even a nuclear third world war in popular imagination as evocatively suggested in the footage of a major war game World War Three: inside the War Room (BBC Two, 2016).

2 Among the twenty nine post-communist nations, in 2016 Estonia ranked first in democratic development, Latvia third and Lithuania ranked fifth, according to Freedom House, a US-based human rights organization, <http://estonianworld.com/business/estonia-ranks-first-freedom-house-democratic-development-index/> (accessed 30 October 2016).
} 
The renewed interest in "why the Baltic states are not Balkans?" therefore seems well-warranted. In order to reconsider the long-term development of the Baltic states in the twentieth century, this special issue invokes the concept of "critical juncture" from social sciences. Following Giovanni Capoccia and Daniel Kelemen (2007), critical juncture is a relatively rare occasion, a "window of opportunity", a situation when structural constraints relax, the pace of events increases rapidly, and political actors face a multitude of choices to remodel existing institutions. The importance and the nature of a critical juncture can only be understood against the backdrop of longer periods of institutional development, during which the role of contingency and the extent of reform are far more modest. The choices that powerful actors make during those periods of rupture are likely to persist, as they tend to generate "path-dependent processes" that determine the nature of institutions over a longer period of time. In their book Why nations fail, Daron Acemoglu and James Robinson trace the impact of critical junctures on economic and political institutions around the globe. One such example is the descent of the bubonic plague on medieval Europe and the diverging of economic developments in Western and Eastern Europe, with the former experiencing the rise of worker's wages and extension of individual rights and the latter seeing the consolidation of serfdom and extractive economic institutions. ${ }^{4}$ Although the concept is elusive, destined to generate debates over which events should be given the mantle of a critical juncture, it is a useful tool to rethink long-term historical trends and particularly the consequences of short-term revolutionary changes.

In this issue we pause on two critical junctures in the Baltic history, the aftermath of the First World War, and the end of the Cold War. The First World War resulted in the collapse of the Russian Empire, giving Germany the opportunity to extend its sphere of influence, its political and military power into the Baltic provinces. As a consequence sovereignty over Baltic peoples, subjects of the Russian Czars since 1721, suddenly became an object of discussion, diplomatic negotiation and military struggle. In contrast to earlier periods when the "Baltic question" had also been fought out between greater nations, this time Baltic political nationalism, a new and unanticipated force, was also thrown into the scales and indeed played a major role in the outcome - the creation of three new states, Estonia, Latvia

\footnotetext{
3 Walter C. Clemens, "Ethnic peace, ethnic conflict: complexity theory on why the Baltic is not the Balkans", Communist and Post-Communist Studies, 43:3 (2010), 245-261.

4 Daron Acemoglu, James Robinson, Why nations fail: the origins of power, prosperity, and poverty (London: Profile Books, 2013).
} 
and Lithuania. Therefore, as we use the term "Baltic question" that implies an outsider's or even an imperial perspective, ${ }^{5}$ we should not forget that the Baltic nations were also important players in the game, at least in the twentieth century. The penultimate and last article of the issue (Stöcker, and Piirimäe/Grönholm) highlight this point in their respective examinations of the role of the "internal" actors in solving the Baltic puzzle after the Cold War.

The other critical juncture under scrutiny relates to the final years of the Cold War. As in the First World War, the independence of Estonia, Latvia and Lithuania was not part of the plan of any of the great powers negotiating a new international system. Just as the First World War had ended without the future of the Baltic states having been settled, the Cold War came to a close leaving the Baltic states in a similar situation. According to the majority view the Cold War ended in 1989-90 with the collapse of the Warsaw Pact and the reunification of Germany, while no major structural changes were initially sought in the Soviet Union. ${ }^{6}$ The Baltic struggle for independence, even though it had manifested itself earlier (1988) and more vocally than popular movements in the Eastern bloc, was largely ignored and later misrepresented in the chronological frames of the end of the Cold War. Indeed, Western governments needed a stable partner in the East to negotiate agreements on arms reduction, departure of Soviet troops from Europe, and other Cold War legacies, as well as in solving new conflicts, such as the Gulf Crisis, to usher in a new era in world politics. All these factors postponed decisions on the "Baltic question" and produced a highly volatile and precarious situation in the Baltic states thereof. Explicating the role of the United States (Olavi Arens), France (Una Bergmane and Louis Clerc), Iceland (Guðni Jóhannesson) and Sweden (Mart Kuldkepp)

\footnotetext{
${ }^{5}$ Authors are grateful to Laur Vallikivi of the University of Tartu for turning attention to those connotations of the term "Baltic question".

6 For a good discussion of various perspectives on the multiple "endings" of the Cold War as an international system, see Reinterpreting the end of the Cold War: issues, interpretations, periodizations, ed. by Silvio Pons and Federico Romero (Abingdon \& New York: Frank Cass \& Routledge, 2005), especially chapters by Odd Arne Westad ("Beginnings of the end: how the Cold War crumbled", 68-81), and Jonathan Haslam ("1989: history is rewritten", 165-178). See also Norman A. Graebner, Richard Dean Burns, Joseph M. Siracusa, Reagan, Bush, Gorbachev: revisiting the end of the Cold War (London: Praeger Security International, 2008); Stephen Kotkin, Armageddon averted: the Soviet collapse, 1970-200o (New York: Oxford University Press, 2003); John Prados, How the Cold War ended: debating and doing history (Washington, DC: Potomac Books, 2011); Vladislav Zubok, "Why did the Cold War end in 1989? Explanations of "The Turn", Reviewing the Cold War: approaches, interpretations, theory, ed. by Odd Arne Westad (London: Frank Cass, 2000), 343-368.
} 
in the process of the Baltic emancipation and the eventual happy end (i.e. the restoration of their independent statehood) in August 1991 is the subject of this special issue.

The first four articles of this issue look at the Baltic independence struggle through the lens of the "Baltic question", a concept that obviously needs some theoretical clarification. According to Walter Kirchner, probably the first author to academically analysz it, the phenomenon refers to "the role which the eastern Baltic region played in world affairs", "the influence which this area exercised upon the development of the surrounding great powers", consisting of a "conflict of interests in the power politics of great nations". Kirchner's interpretation of the Baltic question as an issue affecting "world affairs", and world affairs affecting the Baltic states, is still relevant. However, the nature of that influence should be defined more broadly. Whereas Kirchner focused narrowly on issues of strategy and high politics, this volume takes advantage of the developments in the discipline of international history (Kirchner's study appeared in 1954) and re-interpretations of the Baltic question that have appeared since the 2000 s in particular. In his work dedicated to France's diplomacy towards the Nordic states and especialy Finland, Louis Clerc considered geopolitical incentives but emphasized also subtler forces at play in shaping these relations - from the abstraction of representations and culture to the materiality of personal networks. ${ }^{8}$ It furthermore resonates with the powerful call of the "postcolonial security studies" to investigate "the weak and the strong together, as jointly responsible for making history" and shaping world politics. ${ }^{9}$ It also takes a cue from Kaarel Piirimäe's monograph Roosevelt, Churchill and the Baltic question which has inter alia scrutinized the impact of intellectual history and the development of political ideas on the handling of the Baltic states by the Big Three in the Second World War. ${ }^{10}$ Una Bergmane has dwelled on another layer that has become increasingly important in international politics in the wake of globalization and information revolution,

\footnotetext{
7 Walter Kirchner, The rise of the Baltic question (Westport: Greenwood Press, 1954), 2, 254-257.

8 Louis Clerc, La Finlande et l'Europe du Nord dans la diplomatie française: relations bilaterales et intérêt national dans les considérations finlandaises et nordiques des diplomates et militaires français, 1917-1940 (Bruxelles: P.I.E. Peter Lang, 2011).

9 Tarak Barkawi and Mark Laffey, "The postcolonial moment in security studies", Review of International Studies, 32:2 (2006), 329-352, 333.

10 Kaarel Piirimäe, Roosevelt, Churchill and the Baltic question: allied relations during the Second World War (New York: Palgrave, 2014).
} 
and namely public diplomacy. ${ }^{11}$ Most probably there will never be a singular definiation of public diplomacy, as it depends on historic traditions, cultural practices and other factors, but at its core, as defined by Edmund Gullion in the 1960s, public diplomacy deals with the "influence of public attitudes on the formation and execution of foreign policies". ${ }^{12}$ The crux of the matter is that whereas Ivan the Terrible or Sigismund August, the key players in Kirchner's analysis of the sixteenth-century Europe, could ignore the opinion of their own people or the Livonians they were going to conquer, public opinion has been an increasingly important factor in the twentieth-century foreign policy-making processes. ${ }^{13}$

This volume has thus broadened the scope of Kirchner's original analysis regarding "the Baltic question" and discusses not only strategic concerns of the countries involved, but considers also other factors affecting policymaking, such as cultural perceptions of foreign policy-making elites; the effectiveness of the networks of activists advancing the Baltic cause; the shifting meaning of political concepts (i.e. national self-determination in Arens' chapter); the changing international rules and norms; institutional frameworks in which foreign policy is formulated (bureaucracy, key individuals etc.); and domestic politics. As such, it engages with a panoply of topics that the sub-discipline of Foreign Policy Analysis, straddling Political Science/International Relations and International History has dealt with in extensive detail in recent decades. The papers address the complex interchanges between the domestic and the international, exploring the processing of "the Baltic question" on multiple levels of analysis (ranging from international systemic to state, sub-state, and ultimately, the individual) by different actors (governments and their bureaucracies, domestic and transnational social groups, individual politicians) and conceptual

\footnotetext{
${ }^{11}$ Una Bergmane, French and US reactions facing the disintegration of the USSR: the case of the Baltic states (1989-1991), Sciences Po, Paris, unpublished PhD Thesis; Una Bergmane, "Diplomacy and diasporas, self-perceptions and representations: Baltic attempts to promote independence, 1989-1991", Histories of public diplomacy and nation branding in the Nordic and Baltic countries: representing the periphery, ed. by Louis Clerc, Nikolas Glover, Paul Jordan (Leiden: Brill/Nijhoff, 2015), 195-216.

12 James Pamment, New public diplomacy in the 21st century: a comparative study of policy and practice (New York: Routledge, 2012), 6; Histories of public diplomacy and nation branding.

${ }^{13}$ See, e.g., Douglas Foyle, "Public opinion and foreign policy: elite beliefs as a mediating variable", International Studies Quarterly, 41:1 (1997), 141-170, and "Foreign policy analysis and globalization: public opinion, world opinion and the individual", International Studies Review, 5:2 (2003), 155-202; Ole Holsti, "Public opinion and foreign policy: the challenge to the Almond-Lippmann consensus", International Studies Quarterly, 36:4 (1992), 439-466.
} 
models explaining their respective decisions and actions in policy formulation and implementation. ${ }^{14}$

Moreover, Arens, Bergmane, Clerc and Kuldkepp take a uniquely longterm view by comparing the policies of the governments under scrutiny in two time periods, in 1918-22 and 1988-91. The comparative analysis allows them to approach the following questions:

1. What are the similarities and differences in the opportunities and challenges presented by the "Baltic question" for the countries concerned in 1918-22 and 1988-91?

2. What are the similarities and differences in the position of USA/France/ Sweden in world affairs and in the Baltic region in 1918-22 and 1988-91?

3. To what extent had the international context (including the global norms, domestic political contexts, and globalization) changed by the 1980 ?

These issues are raised with a quest for an improved understanding of the international contexts of the Baltic struggle for independence at the critical junctures in the history of the twentieth century. At a more conceptual level, we are interested in the role of foreign support or the lack thereof in shaping the political outcome in the eastern Baltic region. What kind of shifts in the international system can be historically pinpointed as determining the rise of the Baltic question as an important problem in world affairs? The latter aspect is essential for policy-makers interested in predictions and in precluding certain negative scenarios (like those that unfolded in the Second World War) from materializing for the Baltic states. Last but not least, the experience of the Baltic states might be relevant for other small states, the destinies of which are affected, among other factors, by the unchanging determinant of geography. ${ }^{15}$

\footnotetext{
14 For the background of Foreign Policy Analysis (FPA) as an analytic field, see Valerie Hudson, Foreign policy analysis: classic and contemporary theory (Lanham, MD: Rowman \& Littlefield, 2014). Using history as a tool in the Baltic foreign policy making specifically, see Philippe Perchoc, "History as a tool for foreign policies in the Baltic states after 1991", History, memory and politics in Central, East and South East Europe, ed. by G. Mink and L. Neumayer (New York: Palgrave, 2013), 242-266.

15 See Mouritzen's discussion of the primacy of states' salient environments over the structure of international systems, Hans Mouritzen, "Focus and axioms", Bordering Russia: theory and prospects for Europe's Baltic rim, ed. by Hans Mouritzen (Aldershot: Ashgate, 1998), 1-13. The literature on small states in international politics is too large to do justice here, but see, e.g., Christine Ingebritsen et al., Small states in international relations (Seattle: University of Washington Press, 2006); Olav F. Knudsen, "Small states, latent and extant: towards a general perspective", Journal of International Relations and Development, 5:2 (2002), 182-198; Miriam Fendius Elman, "The foreign policies of
} 
The aspect of geography leads us inevitably to the elephant in the room, namely Russia, the most important factor in the Baltic history during the twentieth century. ${ }^{16}$ This special issue does not include analyses of the Russian or Soviet policies per se. However, the chapters by Lars Fredrik Stöcker and Kaarel Piirimäe/Pertti Grönholm deal with the influence of Russian/Soviet traditions in Baltic societies and the strength of the countervailing Western forces. Stöcker scrutinizes the reception of Western economic ideas and models of management in Estonia before the start of economic perestroika by Mikhail Gorbachev gave economists and entrepreneurs the opportunity to put those ideas into practice. From the perspective of the theory of critical junctures, it could be suggested that the Baltic states' proximity to the West and to Nordic influences (particularly in the case of Estonia) created preconditions for the speedy and successful transfer of Western economic institutions in the area. Meanwhile, a major political change - that is, Gorbachev's relaxation of central controls, presented a window of opportunity. The relatively small differences between the Baltic republics and the other Soviet republics during the Soviet period were therefore translated into different paths of development in Estonia, Latvia and Lithuania on the one hand and Russia, Ukraine and the other former republics on the other. Whether the effect is similar to the impact of the bubonic plague that led to divergent economic practices in Western and Eastern Europe is certainly too early to tell. As only twenty five years have passed since the collapse of the Soviet Union, it is hard to predict to what extent the developments we have witnessed in the former Soviet Union are really path dependent and irreversible, as for example Ukraine is again making an effort of fighting corruption and introducing Western practices, while the Baltic states still face structural problems that are rooted in the Soviet past. ${ }^{17}$

The differences between the former Soviet republics that have magnified since 1991 lead one to consider the importance of not only the Soviet

small states: challenging neorealism in its own backyard", British Journal of Political Science, 25:2 (1995), 171-217.

16 For the 1990s, see Mouritzen, Bordering Russia, 1. Similar conclusion is drawn for the 16th century by Kirchner in Rise, 254.

17 For Ukraine, see Serhiy Kudelia, "Corruption in Ukraine: Perpetuum mobile or the endplay of post-Soviet elites?", Beyond the Euromaidan: comparative perspectives on advancing reform in Ukraine, ed. by Henry E. Hale, Robert Orttung (Stanford: Stanford University Press, 2016), 61-79; on the Baltic states, see a discussion about post-Soviet corruption in Daunis Auers, Comparative politics and government of the Baltic states: Estonia, Latvia and Lithuania in the 21st century (Basingstoke; New York, NY: Palgrave Macmillan, 2015), 136-141. 
period but also of earlier developments since the First World War, which can be conceptualized, borrowing from Reinhart Koselleck, as cumulative historical experiences of people involved in critical situations. Experiences shape horizons of expectation that influence the way people act. ${ }^{18}$ Kaarel Piirimäe and Pertti Grönholm's article scrutinizes the impact that the experience of and the views on the pre-war society of independent Estonia (1918-40) had on people's outlook in the 1980s and the early 199os. The forty years of forced Soviet rule should have formed a common Soviet identity, at least according to the official ideology, but nothing of the sort actually happened. ${ }^{19}$ By comparing the views and ideas of the key players in Estonian foreign policy in 1990-91, Piirimäe and Grönholm come to the conclusion that the self-identification of the generation born before Second World War was strongly attached to the pre-war republic. As a result, the older generation was more likely to reject Soviet traditions and reinstitute pre-war but also Western practices, whereas the post-war generation had often the mentality that the Soviet system could be reformed. The pre-war generation formed a natural coalition with younger people in their twenties and early thirties. The living memory of the "golden age" of independence - something that was lacking in other Soviet republics beside Bessarabia and Bukovina (Western Belarus and Western Ukraine had been part of pre-war Poland and the experiences were somewhat different) - was therefore a key asset in the Baltic states' quest to return to Europe. It contributed to their seemingly smooth transfer from Communism to post-Communism.

We can, therefore, conclude on an optimistic note. Studying the rise of the Baltic question in earlier times, Walter Kirchner observed: "Of all concerned, only the Livonians themselves failed to influence the outcome of the struggle over the Baltic Question which affected their own land so vitally. The sixteenth-century chapter of the Baltic Question had to be solved without their contribution." ${ }^{20}$ From the vantage point of the 1950, he further added that "they remain the unfortunate victims of shifting and powerful forces utterly beyond their own control". In contrast, as this volume demonstrates, the experience of the First World War and the end of

18 Reinhart Koselleck, Futures past: on the semantics of historical time; translated and with an introduction by Keith Tribe (New York; Chichester: Columbia University Press, 2004), 259-75.

19 On the possibility of non-Soviet life styles, see Ainè Ramonaite, "Creating one's own reality as resistance: the shape of 'parallel society' in Soviet Lithuania", Lithuanian Historical Studies, 15 (2010), 79-106.

${ }^{20}$ Kirchner, Rise, 254. 
the Cold War, along with the developments since the 199os could serve as an illustration of the considerably more active and consequential role of Estonians, Latvians and Lithuanians in shaping their own fates in international affairs. This could perhaps provide some comfort in contemporary times of distress when "the Baltic question" is making headlines in "high international politics" yet again. While the credibility of the Baltic commitment to the North Atlantic alliance and NATO's commitment to the Baltic defence in turn has been openly questioned by the by the current President-elect of the United States Donald Trump, ${ }^{21}$ we might stand on the verge of yet another critical juncture in the global handling of "the Baltic question". Regardless of the constraints emphasized by much of International Relations theory, generally skeptical of small states' scope of action in difficult geopolitical environments, the historical record of the Baltic self-determination in twentieth-century international relations comes across as an inspiring example.

${ }^{21}$ See $<$ https://www.washingtonpost.com/news/checkpoint/wp/2016/o7/21/donaldtrump-cast-doubt-on-the-baltics-involvement-in-nato-heres-what-they-actually-do/> (accessed 20 October 2016). 
